\title{
E-Satın Alma Niyeti İnternet ve Sosyal Medya Kullanımı Tarafından Pekiştiriliyor Mu? Üniversite Öğrencileri Üzerine Nicel Bir Araştırma
}

\author{
Nahit Erdem Köker (Doç. Dr.) \\ Ege Üniversitesi İletişim Fakültesi \\ nahit.koker@ege.edu.tr \\ Özgür Köseoğlu (Doç. Dr.) \\ Ege Üniversitesi İletişim Fakültesi \\ ozgur.koseoglu@ege.edu.tr \\ Mehmet Yakın (Dr. Öğr. Üyesi) \\ İstanbul Arel Üniversitesi İletişim Fakültesi \\ mehmetyakin@arel.edu.tr
}

Başvuru Tarihi: 09.05.2018

Yayına Kabul Tarihi: 20.06.2018

Yayınlanma Tarihi: 30.07.2018

\section{Öz}

Sosyal medyanın popülerliği arttıkça çevrimiçi alışveriş olgusuyla iç içe geçtiği söylenebilir. Pazarlamacılar çevrimiçi satın almayı özendirmek için sosyal medyayı tüketicinin başta reklam olmak üzere, çekiliş, yeni ürün tanıtımı, örnek ürün dağıtımı ve indirim mesajlarına maruz kaldığı bir ortama çevirme eğilimindedirler. Üstelik sosyal medya tüketicilerin bazen de pazarlamacıların, çevrimiçi alışverişe yol açabilecek türden ağızdan ağıza mesajlar ürettiği ve çoğalttığı bir merkez haline gelmiştir. $\mathrm{Bu}$ nedenle, söz konusu çalışma sosyal medya kullanımının e-satın alma niyeti oluşturup olușturmadığını anlamaya çalıșmaktadır. Araștırma kapsamında üniversite öğrencilerinin e-alışveriş niyeti algılarını ve sosyal medya kullanım alışkanlarını ölçen bir anket uygulanmıștır. Sonuçlar, internette ve sosyal medyada daha çok vakit geçiren ve sosyal medya hesaplarını daha sık kontrol eden kullanıcıların daha fazla e-alışveriş niyeti geliştirdiğini göstermektedir. Bunlara ek olarak, yeni ürün tanıtımlarını takip eden ve belirli bir markanın hayranı olan kullanıcıların daha güçlü alışveriş niyetine sahip oldukları gözlenmiştir. Sonuçlar aynı zamanda, internetten son bir yılda daha çok sayıda ürün/hizmet satın alanların ve e-alışverişe daha çok para harcayanların, daha güçlü e-satın alma niyetine sahip olduğunu göstermektedir.

Anahtar Sözcükler: İnternet Kullanımı, Sosyal Medya Kullanımı, e-Satın Alma Niyeti. 


\title{
Is E-Purchase Intention Reinforced by The Use of the Internet and Social Media? A Quantitative Study of University Students
}

\author{
Nahit Erdem Köker (Assoc. Prof. Dr.) \\ Ege University Faculty of Communication \\ nahit.koker@ege.edu.tr \\ Özgür Köseoğlu (Assoc. Prof. Dr.) \\ Ege University Faculty of Communication \\ ozgur.koseoglu@ege.edu.tr \\ Mehmet Yakın (Asst. Prof. Dr.) \\ Istanbul Arel University Faculty of Communication \\ mehmetyakin@arel.edu.tr
}

Date Received: 09.05.2018

Date Accepted: 20.06.2018

Date Published: 30.07.2018

\begin{abstract}
As social media grows in popularity, it is seemingly becoming intertwined with online shopping. Marketers tend to turn social media into a platform through which consumers are exposed to all kinds of promotional activities and messages primarily advertisements but also raffle draws, new product introductions, sampling and price reductions in order to increase online purchases. Moreover, today's social media is evidently the hub of e-word of mouth generated and amplified by consumers and in some cases by marketers, which may lead to an increase in online purchases. Therefore, this study aims to discover if the Internet and social media use encourage growth of e-purchase intention. A large sample of university students completed a questionnaire that assessed their e-purchase intention and their social media use. The results indicate that the users who spend more time on the Internet and social media, and those who check their accounts more frequently are more likely to develop e-purchase intention. In addition to these, the users who follow new product introductions on social media and those who are funs of a particular brand establish a stronger e-purchase intention. The results also show that both the users who purchased more items online and the ones who spent more money online during the last year developed a greater e-purchase intention.
\end{abstract}

Keywords: The Internet Use, Social Media Use, e-Purchase Intention. 


\section{Giriş}

Çevrimiçi alışveriş, tüketicilerin giderek daha fazla içinde olmaya başladığı bir olgu olarak karşımızdadır. Geleneksel alışveriş yöntemleri hala varlıklarını sürdürmekle birlikte, çevrimiçi ortamdan alışveriş yapmak da bazı avantajları nedeniyle giderek popülerleşmektedir. Geleneksel mağazaları tek tek dolaşmak, fiyatları karşılaştırmak ve tüm bunları genellikle kent yaşamının karmaşası ve aksak ulaşım koşulları içinde yapmaya çalışmak, çağdaş toplumlarda giderek daha az boş zamana sahip olan bireyler için artık pek de uygun değildir. Ürüne dokunmanın ve onu denemenin önemli olduğu ürün kategorilerinde geleneksel mağaza ziyaretleri hala önemliyken, kitap, CD, elektronik gibi pek çok ürün kategorisi için çevrimiçi alışveriş çekici bir seçenek olmaya başlamıştır.

Chen ve Chang $(2003,564)$ yaptıkları araştırmada, internetten en çok alınan ürün kategorilerini sırasıyla, uçak bileti, kitap, giyim ve aksesuar, bilgisayar ve donanım, elektronik, oyuncak ve vitamin/takviye besinler olarak listelemiştir. Tüketicilerin internetten alışveriş yapmalarının nedenlerini de ortaya koyan araştırmaya göre, geniş bir ürün çeşitliliğine ulaşma, aradığını kolaylıkla bulma, zaman tasarrufu, günün istediği zamanında sipariş verebilme özgürlüğü, ürün bilgilerine ulaşabilme, daha düşük fiyattan alabilme, yeni ürün kategorileri keşfetme, alternatif ürünleri görüp inceleyebilme, güvenli bir alışveriş deneyimi elde etme ve alışveriş̧ deneyimini eğlenceli bulma gibi nedenler saptanmıştır. Ancak bu araştırma 2003 yılında yapıldığı için sosyal medyanın alışveriş deneyimine etkileri konusunda çok fazla bir şey söylememektedir. Hâlbuki günümüzde sosyal medya, tüketicilerde alışveriş niyeti oluşturabilecek türden örgüt (satıcı) ve tüketici yaratımlı mesajlar içeren ortamlar olarak karşımızdadır. Mangold ve Faulds (2009, 357)'a göre, sosyal medya hem örgütlerin müşterileri ile doğrudan iletişim kurma hem de müșterilerin kendileri arasında iletişim kurmalarının yani ağızda ağıza iletişimin önünü açtığı için, tutundurma karmasının melez bir elemanı haline gelmiştir.

\section{Kuramsal Zemin}

\subsection{Geleneksel Medya ve Sosyal Medyanın Pazarlama İletişimi Açısından Karşılaştırılması}

Tüketicilerin ve daha geniş anlamda toplumun yeni buluşma mekânı olan sosyal medya, kalabalık olmaları nedeni ile ürün ve hizmet üreticilerinin göz ardı edemeyecekleri ortamlara dönüşmüştür. Örneğin, Facebook (2018)'un yayınladığı verilere bakıldığında, 2017 Aralık ayı itibariyle 2,13 milyar aktif Facebook kullanıcısı bulunmakta ve her gün ortalama 1,4 milyar kişi sistem içinde etkin olarak yer almaktadır. Kelly $(1998,49)$ 'e göre, yeni ekonomide servet, kıt olanın yarattığı değerden değil, bol olanın kaçınılmazlığından kaynaklanacaktır. Bu bağlamda, dijital teknolojiler, her yerde bulunması, her şeyle senkronize olabilmesi ve yarattığı kalabalıklardan dolayı ekonominin merkezindedirler.

Geleneksel medya, kitlelere hitap edebildiği için pazarlama iletişimi faaliyetlerinin odağı olmuştur. Sosyal medya için durum çok da farklı değildir. Bu ortamlar, farklı ürün ve hizmetlerin tutundurma faaliyetlerinin yapıldığı ortamlardır. Ancak geleneksel medyadan farklı olarak, sosyal medyanın pazarlama iletişimi etkinlikleri açısından markalara sunduğu bazı avantajlar bulunmaktadır.

Geleneksel mecraların kitlelere hitap edebilme olanakları medyadaki parçalanma nedeniyle her geçen gün azalmakladır. Kanal sayısının görece az olduğu dönemlerle, reklamcılar mecralar üzerinden daha geniş yığınlara ulaşabilme becerisine sahipken, 
bugün bunu başarmak daha zor ve maliyetlidir. Sosyal medya da parçalı yapıya sahip olmasına rağmen, parçalar arasında birbiriyle bağlantı olma hali (interconnected) daha yüksektir. Bununla beraber, geleneksel medyada edilgen bir izleyici kavramından söz edilirken, sosyal medyada görece daha etken ve zaman zaman da enformasyon arayan (information seeker) kullanıcı gruplarından söz edilebilir. Bu da örgütlere, belirli bir ürün ve hizmet hakkında enformasyon arayan kullanıcıları saptama ve onlarla pazarlama iletişimi mesajlarını buluşturma olanağı vermektedir.

Özellikle yeni kuşak tüketicilerde yalnızca izleyici olmakla yetinmeme ve içerik üretme eğilimi vardır. Geleneksel medyanın tek yönlü yapısının, bu gereksinimi karşılamakta yetersiz kaldığı söylenebilir. Geleneksel medyanın güç kaybını araştırmalarda da görmek mümkündür. Örneğin İngiltere'de çocukları 90'lı yılların ortalarından beri takip eden bir araştırmaya göre, 2016 yılı, çocuklarda çevrimiçi zaman geçirmenin televizyon izleme oranlarının önüne geçmesi açısından bir dönüm noktası olmuştur (Cohuglan, 2016).

Geleneksel yayın/yayım teknolojisi tek yönlü bir yapıya sahip olduğundan, etkileşimden söz etmek güçtür. Programları ya da reklamları izleyenlerin tam olarak kim olduklarını bilmek ve bu ticari mesajlara maruz kaldıktan sonra ne düşündüklerini kısa sürelerde anlamak olanaksızdır. Medya planlaması belirli tahminlere dayanılarak yapılmaktadır. Pazar bölümlemeleri yine belirli tahminler doğrultusunda ortalamalar esas alınarak gerçekleştirilen maliyetli işlerdir. Her ne kadar sonradan tematik kanallar çlktıysa da mesajlar yeterince kişiselleştirilememekte ve önemli ölçüde ortalamalara hitap etmektedir. Hâlbuki sosyal medyada, ticari mesajların kişiye özel hale getirilebilmesi ve reklamların ayrıntılı hedefleme olanakları, pazarlama iletişimi faaliyetlerini daha etkin hale getirme olanağı sunmaktadır. Tıklama gibi bazı somut eylemlerden yola çıkılarak, kullanıcının ya da tüketicinin niyeti daha sağlıklı bir biçimde anlaşılabilir. Anonim olma olanaklarının giderek azaldığı sosyal medyada, kullanıcıların kim oldukları eskiye oranla daha kolay saptanabilmekte ve yüksek hedefleme yapilabilmektedir. Sözgelimi Facebook bugün reklam verenlere, konum (dünya geneli, serbest ticaret bölgeleri, ülke, eyalet, il, seçim bölgesi, posta kodu, yarıçap hedeflemesi, belirli biryöne hareket eden kullanıcılar vb.) yaş, cinsiyet, dil, bağlam, detaylı hedefleme (kișilerin zaman tünelinde paylaștıkları, tıkladıkları reklamlar, kullandıkları uygulamalar, kullanıcıların Facebook dıșında gerçekleștirdikleri faaliyetler, alışveriş davranışları, satın alma niyetleri, seyahat tercihleri vb.) türünden özelliklerini dikkate alarak hedefleme olanakları sunmaktadır (Facebook, 2018). Bu daraltılmış hedefleme olanakları, doğru zamanda, doğru profildeki tüketicilere daha az maliyetle ulaşma imkânlarını verebilmektedir.

Sosyal medya, örgütlerin yalnızca reklam yayınladıkları bir ortam değildir. Bunun yanında, örgütlerin ürün ve hizmetleri konusunda bilgiler paylaştıkları, yarıșmalar düzenledikleri, çekiliş yaptıkları, hediyeler verdikleri bir mecradır. Örgütler sosyal medyada başlayan bazı olay organizasyonlarını çevrimdışı dünyaya taşıyarak tüketicilerin hem birbiri ile hem de ürünlerle fiziksel buluşmasını da olanaklı kılabilmektedir. Dolayısıyla sosyal medyada etkin bir biçimde ürün hizmet ile ilgili bilgi arayan, fan (hayran) sayfalarını, ürün/hizmet hesaplarını takip eden tüketicileri, reklam mesajları dışında, tutundurmaya yönelik ticari amaçlı pek çok faaliyet beklemektedir. Tüm bunlar, tüketici ile ürün/hizmetler arasındaki bağı (engagement) artırmaya yönelik faaliyetlerdir. 
Bunun yanında, içerikleri daha çok tüketicilerin oluşturduğu ve görece daha az örgüt müdahalesi barındıran tüketici forumları, içerik siteleri ve bloglar da mevcuttur. Bunlar ağızda ağıza iletişim (word of mouth) potansiyeli yüksek sosyal medya platformlarıdır. Ağızdan ağıza iletişimin tüketicinin karar verme süreçlerindeki önemi, pazarlama ve reklam alanyazınında uzun süredir kabul edilmektedir (Engel, Blackwell ve Kegerreis, 1969'dan akt. Shu-Chuan Chu ve Yoojung Kim, 2011, 49). Ürün ve hizmetlerle ilgili çok fazla enformasyonun olduğu, güvenilir bilgiye ulaşmanın güçleştiği ve reklam gibi ticari iletişim formlarından kaçınmanın giderek arttığı günümüz toplumunda, tüketiciler tanıdıkları ya da güvendikleri kişilerden gelen ürün hizmet önerilerini dikkate alma eğilimindedirler. Sweeney, Soutar ve Mazzarol $(2008,344)$ 'a göre, ağızdan ağıza iletişimin tüketicinin seçim yapmak için güven duygusuna daha fazla gereksinim duyduğu alanlarda önemi giderek artmaktadır.

Görüldüğü gibi sosyal medya, geleneksel medyaya oranla çok daha farklı türdeki ticari ve ticari olmayan iletişim biçimlerini içermektedir. Sosyal medyadaki mesajlar, bu bağlamda, örgütten ve örgüt dışı kaynaklardan gelebilir. Örgütten kaynaklanan mesajlar daha çok reklam mesajları ve sosyal medyada tüketiciler ile bağ kurma etkinliklerinden kaynaklanan ürün/hizmet tanıtımları, çekilişler, hediye verme, yarışmalar ve bilgilendirme ve diğer tutundurma amaçlı mesajlar iken örgüt dışından kaynaklanan mesajlar tüketici yaratımlı içeriklerdir ki bunun bir kısmı ağızdan ağıza iletişimden oluşur. Ağızdan ağıza iletişim, doğrudan tüketici kaynaklı organik içerikler olabildiği gibi, örgüt faaliyetleri nedeniyle yapay ve dolaylı olarak oluşmuş da olabilir.

Günümüzde ayrıca, popüler alışveriş sitelerinin sosyal medya özellikleri gösterdiğini görmek de mümkündür. Bu siteler, müşterilerinin profil oluşturmasına ve satın aldıkları ürün ve hizmetler ile ilgili yorum yapmasına ve ürün değerlendirmelerine olanak tanımaktadır.

Özetle, sosyal medyanın, pazarlama iletişimi olanakları açısından geleneksel medyaya göre daha zengin olduğu, geleneksel medyadaki gibi kitlesel ve ortalamaya hitap eden mesajlar yerine kişiye özel mesajlar üretebildiği, ürün/ hizmet tanıtımlarının etkileşimli bir biçimde yapılabildiği, tüketicilerin kendi arasında etkileşiminin mümkün olduğu, ağızdan ağıza iletişimin önünü açtığı ve bu nedenler yüzünden tüketicilerin satın alma niyetini oluşturma konusunda etkili olabileceği düşünülmektedir. Bu bağlamda tüketicilerin sosyal medyada geçirdiği zaman ile çevrimiçi satın alma niyeti geliştirmeleri arasında bir ilişki olması olasılık dâhilindedir.

\section{2. Çevrimiçi Satın Alma Niyeti}

Merriam-Webster'da niyet sözcüğü "belirli bir yönde hareket etme kararlılığı/ direşkenliği" olarak tanımlanmaktadır ("Intention", 2018). Tanımdan da yola çıkılarak, niyet sözcüğünün henüz bir eylem ya da davranış içermediğini ancak niyet sahibi kişinin bunu gerçekleştirmeye ilişkin bir düşüncesinin olduğu söylenebilir. Bu bağlamda niyet, davranış öncesi bir evreyi işaret etmektedir. Tüketici davranışları ile ilgili pek çok kuram, niyet olgusunun tutum ve davranış arasındaki ilişkiyi anlamayı kolaylaştırdığını vurgulamaktadır (Bagozzi, Baumgartner ve Yi, 1989, 35). Davranışların, tutumlar tarafından nasıl ve ne zaman etkilendiğine dair yapılan araştırmaların çoğu ise, Ajzen tarafından geliştirilen Planlanmış Davranış 
Kuramı'ndan etkilenmiştir (Kağıtçıbaşı, 2006, 115). Ajzen'in de belirttiği gibi, Planlanmış Davranış Kuramı, Mantıksal Eylem Kuramı'nın bir uzantısıdır ve Planlanmıș Davranış Kuramı'nda da, Mantıksal Eylem Kuramı'nda olduğu gibi, niyet olgusu, bireyin belirli bir davranışı gerçekleştirmek üzere sahip olduğu merkezi bir faktör olarak değerlendirilir. Niyetlerin bir davranışı etkileyen güdüsel faktörleri denetlediği varsayılır ki bunlar, insanların söz konusu davranışı gerçekleştirmek için denemeye ne denli razı oldukları ya da ne kadar çaba sarf edecekleri konusundaki göstergelerdir. Bu bağlamda, niyet ne kadar güçlü olursa, davranışı gerçekleștirme olasılığının da o kadar yüksek olması beklenir (Ajzen, 1992, 181). Daha genel bir anlatımla, her iki kuramda da insanların gerçekleştirecekleri davranışlar hakkında önceden düşündükleri, bir karara vardıkları ve bunu uyguladıkları vurgulanır ki niyet burada, tutum ile davranış arasında yer alan bir ara değişken gibi işlev görür (Kağıtçıbaşı, 2006, 115).

Söz konusu satın alma davranışı olunca buradaki niyet, satın alma davranışından önceki bir kararlılık durumu olarak düşünülebilir. Morrison $(1979,65)$ 'a göre satın alma niyeti pazarlamada önemli bir kavramdır çünkü reklamların etkinliğini anlamada, tüketicilere daha iyi hitap eden ürün tasarımları yapmada ve pazar bölümlemede kullanılmaktadır. Leelayouthayotin $(2004,128)$ çevrimiçi satın alma niyetini, bireyin karar verme sürecinin tamamlandığı ancak satın alma davranışının gerçekleşmediği bir evre olarak tanımlamaktadır. Çevrimiçi satın alma niyeti aynı zamanda, kullanıcıların yeni bir teknolojiyi kabul derecelerinin güvenilir bir göstergesi olarak da düşünülebilir (San Martin ve Herrero, 2012, 341). Planlanmış Davranış Kuramı'nda da belirtildiği gibi, kişinin tutumu, öznel normları ve algıladığı davranışsal kontrolü, kişinin niyetini, niyeti de davranışını etkiler (Ajzen, 1992, 182).

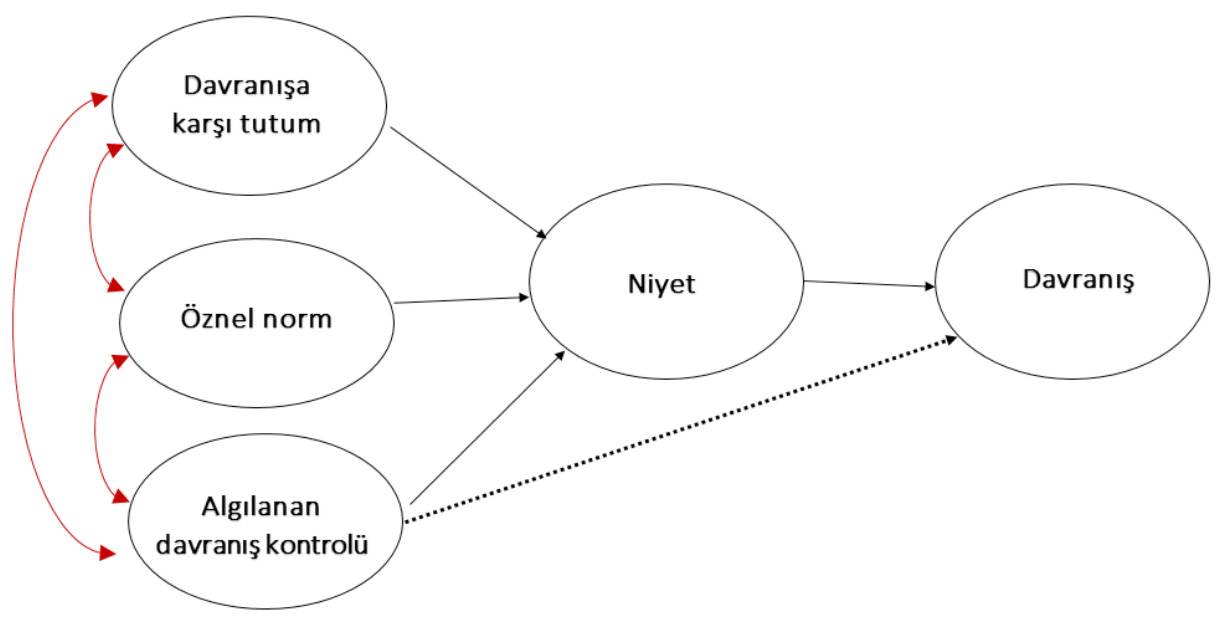

Şekil 1: Planlanmış Davranış Kuramı (Azjen, 1991, 182).

Bu bağlamda, çevrimiçi satın alma niyeti olan bir kullanıcının, internet teknolojisine karşı olumlu bir tutum sahibi olması ("teknoloji özünde iyi bir şeydir" , "teknolojik gelişmelere uyum sağlamak gerekir", "teknoloji bana zaman ve para tasarrufu sağlar" vb.), yakın toplumsal çevreye uyumla ilişkili olan öznel normlarının ve inançlarının olumlu olması ("çevremdeki insanlar internetten alışverişin iyi bir şey olduğunu düşünüyor", "internetten alışveriş bir çağdaşlık göstergesidir") ve algılanan kontrol açısından da eylemi kolay bulması, süreci kontrol edebileceğine ilişkin algısının olumlu yönde olması ("internetten alışveriș yapmak kolaydır" vb.) beklenir. 
Tüketicilerin sosyal medyada vakit geçirirken, onların tutumlarını, öz normlarını (değerlerini ve inançlarını ve ait oldukları topluluğun üzerindeki etkilerini) ve eyleme geçmek için algıladıkları kontrol duygusunu etkileyebilecek türden mesajlarla karşılaşmaları olasılık dâhilindedir.

\subsection{Sosyal Medyadaki Ticari Mesajların Etkinliği ve Satın Alma Niyeti Oluşturmasına Yönelik Araştırma Alanyazını}

Örgütten kaynaklanan mesajlarda en önemli kalemi reklamlar oluşturmaktadır. Reklamdan kaçınma, geleneksel medyada oldukça eski bir olgudur (Speck ve Elliott, 1997, 61). Bu olgunun sosyal medyada da var olduğu söylenebilir. $\mathrm{Bu}$ bağlamda, yüksek hedefleme yapma ve kişiselleştirme olanağı vermesine rağmen, reklam mesajlarının sosyal medyada etkin olduğuna dair kesin olumlama yapılamamaktadır. Sözgelimi, Hadija, Barnes ve Hair $(2012,29)$ sosyal ağ kullanıcılarının reklamları fark etmekte zorlandıklarını saptamıştır. Köseoğlu (2013, 97), üniversite öğrencileri üzerinde yaptığı araștırmada kullanıcıların Facebook ağındaki reklamlarla fazla ilgilenmediklerini, ağızdan ağıza iletişime de sıklıkla girmediklerini göstermiştir. Bununla birlikte, aynı araştırmada, çevrimiçi satın almaya yönlendirme açısından ağızdan ağıza iletişimin reklamlardan daha etkili olduğu görülmüştür. Mikalef, Giannakos ve Pateli $(2013,27)$ ise kişiselleștirilmiş reklamların sosyal medya platformlarında ürün/hizmet arama (product browsing) açısından kullanıcıların faydacı güdülenmelerini etkilemediğini saptamıştır. Sashittal, Sriramachandramurthy ve Hodis $(2012,495)$ kolej öğrencileri üzerine yaptıkları araştırmada, kullanıcıların başka insanların hayatlarını gözetlemek, kendileri için ayırt edici bir kimlik yaratmak ve içsel narsistik arzularına göre hareket etmek gibi üç temel güdüyle hareket ettiklerini keşfetmiş, bu durumun Facebook reklamlarının etkinliğini azalttığını ve pazarlamacıların marka inşa etme süreçlerini baltaladığını belirtmiştir. Windels, Heo, Jeong, Porter, Jung, ve Wang $(2018,420)$ 'ın yaptığı çalışmaya göre ise, kullanıcılar arkadaş referansı taşımayan Facebook reklamlarına, arkadaş referansı taşıyan reklamlardan daha uzun süre dikkat kesilmektedir. $\mathrm{Bu}$ durum referanslı reklam formatının beklendiği kadar etkili olmadığı göstermektedir. Araştırmaya göre, mahremiyet kaygıları taşıyan kullanıcılarda bu durum daha da belirginleşmektir.

Ancak sosyal medyada reklamların etkili olduğuna dair araştırma sonuçları da mevcuttur. Sözgelimi, Dehghani ve Tumer $(2015,598)$ 'in üniversite öğrencileri üzerinde yaptıkları araștırmaya göre, Facebook reklamları, satın alma niyetinin oluşumuna önemli ölçüde katkı sağlayan marka imajı ve marka denkliğini olumlu yönde etkilemektedir. Çelebi $(2015,312)$ 'nin üniversite öğrencileri üzerinde yaptığı araştırmada, Facebook'u aktif bir biçimde kullanmanın, internet reklamcılı̆̆ına ilişkin tutum ve davranışları olumlu yönde etkilediği ortaya çıkmıştır. Ertugan (2017, 132) da öğrenciler üzerinde bir araştırma yapmış ve Facebook reklamlarının etkili olduğunu bulmuştur. Bu platformun ayrıca yeni ürünlerin sunumu konusunda bașarılı bir mecra olduğunu keşfetmiştir. Balakrishnan, Dahnil ve Yi $(2014,183)$ Malezyalı üniversite öğrencileri üzerinde yaptıkları araştırmada, sosyal medyadaki pazarlama çalışmaları kapsamında özellikle ağızdan ağıza iletişim, çevrimiçi topluluklar ve reklamların satın alma niyeti oluşturmada etkili olduklarını görmüşlerdir.

Alanyazına bakıldığında, elektronik ağızdan ağıza iletişimin satın alma niyeti üzerindeki etkisinin olumlu olduğu görülebilir. Erkan ve Evans (2016, 47)’ın üniversite öğrencileri üzerinde yaptığı araştırmaya göre, enformasyona karşı olan 
tutum, enformasyona olan gereksinim, enformasyonun benimsenmesi, yararlılık, kalite ve inanılırlık, sosyal medyadaki elektronik ağızdan ağıza iletişimin satın alma niyetini etkileyen önemli faktörleri arasında yer almaktadır. Shu ve Scott $(2014,286)$ 'a göre sosyal medyadaki tüketici üretimli içerik ve ağızdan ağıza iletişim destinasyon kararı verirken önemli birer faktördür. Hudson ve Thal (2013, 156)'a göre, sosyal medya tüketici karar verme sürecini önemli ölçüde değiştirmiş durumdadır. Sözgelimi seyahat konusunda tüketiciler karar verirken, (1) düşünme/ dikkate alma, (2) değerlendirme, (3) satın alma ve (4) hoşuna gitme/destekleme/bağ kurma gibi dört temel süreçten geçmektedir. Sosyal medya özellikle değerlendirme ve destekleme süreçlerini birbirine bağlantılı hale getirmiştir. Hussain, Ahmed, Jafar, Rabnawaz ve Jianzhou $(2017,96)$ ise tüketicilerin elektronik ağızdan ağıza iletişimi algılanan riski düşürmek ve dolayısı ile karar sürecinde olası zararları aza indirgemek için kullandıklarını belirtmektedir.

Park ve Kim $(2016,1712)$ moda ürünleri üzerinde yaptığı bir araştırmada, sosyal medyada ürün arama (product browsing) ile satın alma niyeti arasında olumlu bir ilgileșim saptamıştır. Buna göre, faydacı alışveriş güdüsü ürün aramayı, satın alma niyetini ve ağızdan ağıza mesaj üretmeyi doğrudan etkilemektedir. Bu bağlamda da sosyal medya sitelerinde ne kadar çok ürün araması yapılırsa, satın alma niyeti de o denli artmaktadır. Bununla birlikte hazcı güdülere sahip kullanıcılar, ürün araması yapmadan ve satın alma niyeti taşımadan arkadaşlarına ürünlerle ilgili yorum yapmaktadırlar. Wang, Yu ve Wei $(2012,198)$ sosyal medyada akran iletişimi yoluyla tüketici sosyalleşmesinin gerçekleștiği sanal dünyaları incelemiş ve akran iletişiminin, kullanıcıları belirli bazı ürün ve hizmetlerle tanıştırdığını saptamış, bu tanışıklığın da zaman içinde kullanıcılarda satın alma niyeti oluşturduğunu göstermiştir. Gunawan ve Huarng $(2015,1)$ sosyal medya kullanıcıları üzerinde yaptıkları araştırmada, kaynağın inanırlığının ve sosyal etkinin, enformasyonun yararlığı ve öznel normlar üzerinde olumlu bir tutum yaratmaya neden olduğunu, bunun da tüketicinin satın alma niyetini güçlendirdiğini saptamışlardır.

Pereira, de Fátima Salgueiro ve Mateus $(2014,695)$ Facebook'ta hayran (fan) kullanıcıların markalarla temas kurmaya gönüllü olmakla birlikte, etkileşime fazla girmediklerini ve marka ile ilgili içerikleri sıklıkla paylaşmadıklarını ortaya koymuştur. King, Racherla ve Bush $(2014,10)$ çevrimiçi ortamdaki kişisel değerlendirmelerin tüketicilerin satın alma kararlarının ne ölçüde etkilediğinin hala tam olarak yanıtlanamadığını, bütün ağızdan ağıza mesajların aynı etkiye sahip olmadığını, tüketicilerin mesajları değerlendirirken enformasyonun kalitesini ve kaynağın karakteristiğini dikkatle irdelediğini ve buna dayanarak mesajı ret ya da kabul ettiğini belirtmektedir. Ancak alan yazına bir bütün olarak bakıldığında sosyal medyadaki ağızdan ağıza iletişimin satın alma niyetini olumlu yönde etkileyebileceği görülmektedir.

Yukarıda sözü edilenlerden hareketle, bu araştırma, internette ve daha özelinde sosyal medyada zaman geçirmenin ve etkileşime girmenin, ortamın ikna edici ticari ve ticari olmayan (reklam, diğer tutundurma çabaları ve ağızdan ağıza iletişim) mesajlar içermesi nedeniyle çevrimiçi satın alma niyeti oluşturup oluşturmadığını keşfetme üzerine kurulmuştur.

Konunun teorik çerçevesi ve oluşturulan araştırma planından yola çıkarak geliştirilen araştırma hipotezleri aşağıdaki şekildedir; 
- $\mathbf{H}_{\mathbf{1}}$ : Gün içinde internette geçirilen sürenin çevrimiçi satın alma niyeti üzerinde anlamlı bir etkisi vardır.

- $\mathbf{H}_{2}$ : Gün içinde sosyal medyada geçirilen sürenin çevrimiçi satın alma niyeti üzerinde anlamlı bir etkisi vardır.

- $\mathbf{H}_{3}$ : Günlük sosyal medya ziyaret sıklığının çevrimiçi satın alma niyeti üzerinde anlamlı bir etkisi vardır.

- $\mathbf{H}_{4}$ : Sosyal medyada marka hayranlığının çevrimiçi satın alma niyeti üzerinde anlamlı bir etkisi vardır.

- $\mathbf{H}_{5}$ : Sosyal medya üzerinden yeni ürün takibinin çevrimiçi satın alma niyeti üzerinde anlamlı bir etkisi vardır.

- $\mathbf{H}_{6}$ : Son bir yıl içerisinde internetten alınan ürün sayısının çevrimiçi satın alma niyeti üzerinde anlamlı bir etkisi vardır.

- $\mathbf{H}_{7}$ : Son bir yıl içerisinde internetten alınan ürünlere harcanan para miktarının çevrimiçi satın alma niyeti üzerinde anlamlı bir etkisi vardır.

\section{Yöntem}

\subsection{Araştırmanın Amacı}

Ege Üniversitesi, İletişim Fakültesi örnekleminde gerçekleştirilen araştırma kapsamında, internette ve sosyal medyada zaman geçirmenin, tüketicilerde daha çok çevrimiçi satın alma niyeti oluşturup oluşturmadığı keşfedilmeye çalışılmıştır. $\mathrm{Bu}$ kapsamda kullanıcıların internet ve sosyal medya kullanım pratiklerinin çevrimiçi satın alma niyeti ve internet üzerinden yapılan alışveriş davranışı ile ilişkisi gözlemlenmiştir.

\section{2. Örneklem}

Araştırmanın çalışma evrenini, Ege Üniversitesi, İletişim Fakültesi lisans öğrencileri oluşturmaktadır. Çevrimiçi satın alma niyeti her yaş grubunda gözlemlenebilmektedir ancak genç tüketici grubuna doğru inildiğinde hem internetten yapılan alışveriş davranışlarında hem de internet ve sosyal medya ortamlarında geçirilen sürelerde artış gözlenmektedir (Lenhart, Purcell, Smith ve Zickuhr, 2010, 5-7, Vrechopoulos, Siomkos, Doukindis, 2001, 145, Sorce, Perotti, Widrick, 2005, 122-132). Bu nedenle araştırılan konu ile ilgili davranışları temsil eden en uygun grubun lisans öğrencileri olduğu düşünüldüğünden araştırmanın evreni lisans öğrencileri olarak belirlenmiştir.

Araștırma için belirlenen çalışma evreni (2243 öğrenci) üzerinde araştırmanın eknik sınırlılıklarından dolayı tam sayım yapabilmenin mümkün olmamasından dolayı örneklem alınmıştır. Mevcut çalışma kapsamında veriler tesadüfî örnekleme yöntemi kullanılarak toplanmıştır. Çalışma kapsamında 602 kişiye anket uygulanmıștır. Araștırmacılar tarafından uygulanan 602 anketin 18 tanesi cevap vermeme, hatalı ve dikkatsiz doldurma gibi nedenlerden dolayı elenmiştir. 584 katılımcıya ait veriler istatistiksel değerlendirmeye tabi tutulmuştur.

\subsection{Veri Toplama Aracı}

İlgili çalışma kapsamında yürütülen alan araştırmasında birincil verilere ulaşabilmek için anket tekniği kullanılmıştır. Araştırmanın doğasına en uygun anketin tasarlanabilmesi için ilgili alanyazın taranmıştır. Gerçekleştirilen alanyazın taramasının ardından katılımcıların internetten alışveriş davranış pratiklerini gözlemleyebilmek için Çelik'in $(2009,200)$ araştırmasında kullandığı veri toplama 
aracı temel alınmıştır. Bu kapsamda ilgili araştırmada gözlemlenen "çevrimiçi satın alma niyeti" mevcut çalışmada da kullanılmıştır. Çelik $(2009,200)$ tarafından geliştirilen veri toplama aracı Moon ve Kim, (2001); Chen, Gillenson ve Sherrell (2002); Suh ve Han, (2002); Kim vd., (2008); Wang ve Head, (2007); Crespo ve del Bosque, (2008) çalışmalarından uyarlanmıştır. Ayrıca katılımcıların sosyal medya ve internet kullanım pratiklerini gözlemleyebilmek için ise Köseoğlu $(2012,69-71)$ tarafından geliştirilen veri toplama aracı temel alınmıștır.

İlgili alanyazın temel alınarak hazırlanan veri toplama aracının sorularının genel anlamda lisans öğrencilerinin dil ve anlam yapısına uygun olması istenmiştir. $\mathrm{Bu}$ kapsamda teknik terim ve kavramlar olabildiğince günlük dile uygun kullanılmıştır. Ayrıca çalışmadaki veri toplama aracının anlaşılabilirliğini gözlemlemek için anket soruları hakkında, örneklem içerisinden alınan küçük bir grup ile görüşmeler yapılmıştır. Veri toplama aracının anlaşılabilirliği doğrulandıktan sonra hazırlanan anket formu örneklem kitlesine uygulanmıştır.

\section{Bulgular}

\subsection{Katılımcıların Demografik Profili}

Araștırmaya katılan katılımcıların demografik özellikleri analiz edildiğinde katılımcıların \%50'sinin kadın, \% 45,7'sinin ise erkekler oluşturmaktadır. Katılımcıların ikametgâh özelliklerine bakıldığında çoğunluğun $(\% 41,1)$ ailesinden ayrı evde kaldığı gözlemlenmiştir. Yaş aralıklarına bakıldığında ise katılımcıların en yoğun olduğu yaş aralığının \%55,5 ile 21-24 yaş arası olduğu tespit edilmiştir.

Tablo 1: Demografik Veriler ( $n=584$ )

\begin{tabular}{|c|c|c|c|c|c|}
\hline & Frekans (F) & Yüzde (\%) & & Frekans (F) & Yüzde (\%) \\
\hline \multicolumn{3}{|l|}{ Cinsiyet } & \multicolumn{3}{|l|}{ İkametgah } \\
\hline Kadın & 292 & 50.0 & Aile Yanında & 163 & 27.9 \\
\hline Erkek & 214 & 45.7 & Ayrı Evde & 240 & 41.1 \\
\hline Boş & 25 & 4.3 & Yurtta & 155 & 26.5 \\
\hline \multirow[t]{3}{*}{ Toplam } & 584 & 100.0 & Diğer & 11 & 1,9 \\
\hline & & & Boş & 15 & 2.6 \\
\hline & & & Toplam & 584 & 100.0 \\
\hline \multicolumn{3}{|l|}{ Yaş } & \multicolumn{3}{|c|}{ Kaç Yıldır İnternet Kullanıyor? } \\
\hline $17-20$ Arası & 192 & 32.9 & 3 Yila Kadar & 56 & 9.6 \\
\hline $21-24$ Arası & 324 & 55.5 & $4-9$ Yıl Arası & 394 & 67.5 \\
\hline 25 ve Üstü & 54 & 9.2 & 10 Yıl ve Üstü & 133 & 22.8 \\
\hline Boş & 14 & 2.4 & Boş & 1 & 0.2 \\
\hline Toplam & 584 & 100.0 & Toplam & 584 & 100.0 \\
\hline \multicolumn{3}{|c|}{ Gün İçinde Ortalama İnternete Girme Süresi } & \multicolumn{3}{|c|}{ Gün İçinde Ortalama Sosyal Medyaya Girme Süresi } \\
\hline 2 Saate Kadar & 288 & 49.3 & 1 Saate Kadar & 177 & 30.3 \\
\hline 2 ile 5 Saat Arası & 215 & 36.8 & $1-2$ Saat Arası & 238 & 40.8 \\
\hline 5 Saatin Üzerinde & 77 & 13.2 & 2 Saat Üzerinde & 152 & 26.0 \\
\hline Boş & 4 & 0.7 & Boş & 17 & 2.9 \\
\hline Toplam & 584 & 100.0 & Toplam & 584 & 100.0 \\
\hline \multicolumn{3}{|c|}{ Son 1 Yılda İnternetten Kaç Ürün Aldığı? } & \multicolumn{3}{|c|}{ Son 1 Yılda İnternetten Alışverişte Ne Kadar Para Harcadı? } \\
\hline Hiç & 56 & 9.6 & Hiç & 132 & 22.6 \\
\hline $1-5$ Ürün & 208 & 35.6 & $1-250$ TL. & 210 & 36.0 \\
\hline 6 ve Üzeri & 132 & 22.6 & 251 ve Üstü & 151 & 25.9 \\
\hline Boş & 188 & 32.2 & Boş & 91 & 15.6 \\
\hline Toplam & 584 & 100.0 & Toplam & 584 & 100.0 \\
\hline
\end{tabular}


Ölçme aracının güvenilirliğinin kontrolü için Cronbach's Alfa iç tutarlılık katsayısına bakılmıştır. Yapılan analizde ölçme aracının iç tutarlılık güvenilirlik katsayısı 0.89 olarak gözlemlenmiştir. Ayrıca kullanılan ölçekte yer alan sorulardan herhangi birisinin çıkarılması halinde de elde edilen Cronbach Alfa değerlerinin artmadığı tespit edilmiştir.

\subsection{Doğrulayıcı Faktör Analizi}

Veri toplama aracının istatistiksel anlamda ölçüm geçerliliği doğrulayıcı faktör analizi ile test edilmiştir. Doğrulayıcı faktör analizine ilişkin veriler Tablo 2'de sunulmuştur. İlgili tablo incelendiğinde ölçme aracının temel yapısını oluşturan her bir maddenin ölçmeye çalıştığı davranışa anlamlı bir etkide de bulunduğu gözlemlenmiştir. Anlamlı etkileri gözlemlenen bu maddelerin yüklerinin istatistiksel olarak sinır değerlerinin üzerinde olduğu görülmektedir. Bu veri, toplama aracındaki bütün soruların ölçmeye çalıştığı davranışa katkıda bulunduğunun somut kanıtı niteliğindedir. Ayrıca doğrulayıcı faktör analizinin başarılı olarak nitelendirilebilmesi için analiz sonucunda ulaşılan uyum iyiliği indeks değerlerinin de tartışılması gerekmektedir.

Tablo 2: Ölçme Modeline İlişsin Parametreler

\begin{tabular}{|c|c|c|c|c|c|c|c|c|c|}
\hline \multicolumn{3}{|c|}{ Faktörler } & & Ortalama & \multicolumn{2}{|c|}{ Standart Sapma } & \multicolumn{2}{|c|}{ Madde Yükü } & C.Alfa \\
\hline \multicolumn{10}{|c|}{ Çevrimiçi Satın Alma Niyeti } \\
\hline \multicolumn{3}{|l|}{ Soru 1} & & 2.56 & \multicolumn{2}{|c|}{1.23} & \multicolumn{2}{|c|}{0.61} & \multirow{4}{*}{0.89} \\
\hline \multicolumn{3}{|l|}{ Soru 2} & & 3.31 & \multicolumn{2}{|c|}{1.31} & \multicolumn{2}{|c|}{0.87} & \\
\hline \multicolumn{3}{|l|}{ Soru 3} & & 3.27 & \multicolumn{2}{|c|}{1.26} & \multicolumn{2}{|c|}{0.94} & \\
\hline \multicolumn{3}{|l|}{ Soru 4} & & 2.90 & \multicolumn{2}{|c|}{1.25} & \multicolumn{2}{|c|}{0.83} & \\
\hline \multicolumn{10}{|c|}{ Doğrulayıcı Faktör Analizi Uyum İndeksleri } \\
\hline$x 2 / s d$ & $p$ & RMSEA & $\mathrm{CFI}$ & AGFI & SRMR & $\mathrm{NFI}$ & NNFI & IFI & GFI \\
\hline 0.282 & 0.595 & 0.002 & 0.980 & 0.842 & 0.030 & 0.982 & 0.936 & 0.982 & 0.973 \\
\hline \multicolumn{10}{|c|}{$\begin{array}{l}\text { - Veri toplama aracının bütününün “Cronbach's Alpha” güvenilirlik değeri: 0.82 / KMO: 0.929. } \\
\text { - Tüm alt faktörlere ait Cronbach Alpha değerleri, önerilen değer olan 0.70'in üzerindedir. } \\
\text { Sipahi, Yurtkoru ve Çinko'ya (2008:89)'a göre Cronbach Alpha değerinin 0,70 } \\
\text { ve üstü olduğu durumlarda ölçeğin güvenilir olduğu kabul edilmektedir. } \\
\text { - Her madde 5'li “Likert” tipi ölçüm sıkalasına göre, } 5 \text { (tamamen katılıyorum), } \\
1 \text { (tamamen katılmıyorum) şeklinde dizayn edilmiştir. }\end{array}$} \\
\hline
\end{tabular}

Tablo 2 incelendiğinde ölçüm modeline ilişkin bütün uyum iyiliği değerlerinin $\left(\mathrm{x}^{2 /}\right.$ $\mathrm{sd}=0.282, \mathrm{p}=0.595, \mathrm{RMSEA}=0.002, \mathrm{CFI}=0.980, \mathrm{AGFI}=0.842, \mathrm{SRMR}=0.030, \mathrm{NFI}=0.982$, NNFI=0.936, IFI=0.982, GFI=0.973) alanyazında belirtilen (Şimşek, 2007, 14, Byrne, 2013, 112, Schumacker ve Lomax, 2004, 82, Bagozzi, 1981, 375-381; Jöreskog ve Sörbom, 1982, 404-416) sınırların içerisinde olduğu gözlemlenmiştir. Bu bulgular, araştırma kapsamında veri toplama aracının ölçüm sürecini gerçekleștirdiğinin bir kanıtıdır. Dolayısıyla yapılan testler ile veri toplama aracına ilişkin tüm bulguların, veri toplama aracında kullanılan ölçeklerin geçerliliği ve güvenilirliklerine kanıt niteliğinde olduğu düşünülmektedir (Anderson ve Gerbing, 1988, 411-423).

\subsection{Verilerin Analizi}

Araștırma kapsamında elde edilen veriler analiz edilirken öncelikle fark testlerine başvurulmuştur. Bu kapsamda çevrimiçi satın alma niyetinin gün içinde internette geçirilen süreye göre anlamlı olarak farklılaşıp farklılaşmadığını gözlemlemek için fark testleri yapılmıştır. Yapılan fark testlerinin sonuçları Tablo 3'deki gibidir. Tablodan da görüleceği üzere katılımcıların gün içinde internette geçirdikleri süreler çevrimiçi satın alma niyeti üzerinde anlamlı farklılaşmalara neden olmaktadır. 
Anlamlı farklılaşmaların olduğu gruplar Tablo 3'de işaretlenmiştir. Bu gruplar incelendiğinde, internette daha fazla süre geçiren gruplar, farklılaşmaların olduğu faktörlerde daha yüksek ortalama puan elde etmiştir. Bu internette geçirilen sürenin çevrimiçi satın alma niyetinde bir artışa neden olduğunun göstergesidir. Dolayısı ile çalışmanın birinci hipotezi kabul edilmiştir.

Tablo 3: Gün İçinde İnternette Geçirilen Ortalama Süre

\begin{tabular}{|c|c|c|c|c|c|c|}
\hline \multicolumn{7}{|c|}{ Bağımsız Değişken: Güniçinde İnternette Geçirilen Süre } \\
\hline Bağımlı Değişken & Bağımsız Değişken & $\mathbf{N}$ & Ortalama & $\begin{array}{c}\text { Standart } \\
\text { Sapma }\end{array}$ & $\mathbf{F}$ & $\mathbf{p}$ \\
\hline \multirow{3}{*}{$\begin{array}{l}\text { Çevrimiçi Satın } \\
\text { Alma Niyeti }\end{array}$} & 2 Saate Kadar & 288 & 2.80 & 1.13 & \multirow{3}{*}{11.733} & \multirow{3}{*}{$\mathrm{p}<0.01$} \\
\hline & 3 ile 5 Saat Arası & 215 & 3.17 & 1.01 & & \\
\hline & 6 Saat ve Üzeri & 77 & 3.35 & 1.09 & & \\
\hline \multicolumn{7}{|c|}{$\begin{array}{l}\text { * Bağımlı değişkenin Skewness - Kurtosis istatistiği puanı }-1.5<x<+1.5 \\
\text { aralığında olduğu gözlemlendiğinden ve bağımsız değişken içerisinde ikiden } \\
\text { fazla grup olduğundan "One Way Anova" testi uygulanmıştır. }\end{array}$} \\
\hline Bağımlı Değişken & Bağımsız Değişken & $2 S$ & e Kadar & $\begin{array}{c}3 \text { ile } 5 \text { Saat } \\
\text { Arası }\end{array}$ & \multicolumn{2}{|c|}{6 Saat ve Üzeri } \\
\hline \multirow{3}{*}{$\begin{array}{l}\text { Çevrimiçi Satın } \\
\text { Alma Niyeti }\end{array}$} & 2 Saate Kadar & & - & * & \multicolumn{2}{|c|}{ * } \\
\hline & 3 ile 5 Saat Arası & & * & - & \multicolumn{2}{|c|}{-} \\
\hline & 6 Saat ve Üzeri & & * & - & \multicolumn{2}{|c|}{-} \\
\hline
\end{tabular}

Tablo 4 incelendiğinde gün içinde sosyal medyada geçirilen sürenin "çevrimiçi satın alma niyeti" üzerinde anlamlı farklılıklar oluşturduğu gözlemlenmiştir. Dolayısı ile sosyal medyada geçirilen sürenin katılımcıların çevrimiçi alışveriş niyetlerine etkide bulunduğu söylenebilmektedir. Tablo 3'ten de anlaşılacağı üzere sosyal medyada 1 saate kadar zaman geçirenler ile 3 saat ve üzeri zaman geçirenler arasında anlamlı farklılıklar gözlemlenmiştir. Farkın gözlemlendiği her iki gruba dair verilere bakıldığında, sosyal medyada 3 saat ve üzeri zaman geçirenlerin 1 saat ve daha az zaman geçirenlere oranla "çevrimiçi satın alma niyeti" ortalamalarının daha yüksek olduğu belirlenmiștir. Dolayısı ile bu sosyal medyada geçirilen sürenin artmasının çevrimiçi satın alma niyetini desteklediğinin bir göstergesi niteliğindedir. Bu sebeple çalışmanın ikinci hipotezi kabul edilmiştir.

Tablo 4: Gün İçinde Sosyal Medyada Geçirilen Süre Fark Testleri

\begin{tabular}{|c|c|c|c|c|c|c|c|}
\hline \multicolumn{8}{|c|}{ Bağımsız Değişken: Güniçinde Sosyal Medyada Geçirilen Süre } \\
\hline Bağımlı Değişken & Bağımsız Değişken & $\mathbf{N}$ & Ortalama & $\begin{array}{l}\text { Standart } \\
\text { Sapma }\end{array}$ & \multicolumn{2}{|c|}{$\mathbf{F}$} & p \\
\hline \multirow{3}{*}{$\begin{array}{l}\text { Çevrimiçi Satın } \\
\text { Alma Niyeti }\end{array}$} & 1 Saate Kadar & 177 & 2.84 & 1.11 & \multirow{3}{*}{\multicolumn{2}{|c|}{5.351}} & \multirow{3}{*}{$\mathrm{p}<0.01$} \\
\hline & 1 ile 2 Saat Arası & 238 & 3.01 & 1.13 & & & \\
\hline & 3 Saat ve Üzeri & 152 & 3.23 & 1.01 & & & \\
\hline \multicolumn{8}{|c|}{$\begin{array}{l}\text { * Bağımlı değişkenin Skewness - Kurtosis istatistiği puanı }-1.5<x<+1.5 \\
\text { aralığında olduğu gözlemlendiğinden ve bağımsız değişken içerisinde ikiden } \\
\text { fazla grup olduğundan "One Way Anova" testi uygulanmıştır. }\end{array}$} \\
\hline Bağımlı Değişken & Bağımsız Değişken & \multicolumn{2}{|c|}{1 Saate Kadar } & \multicolumn{2}{|c|}{1 ile 2 Saat Arası } & \multicolumn{2}{|c|}{3 Saat ve Üzeri } \\
\hline \multirow{3}{*}{$\begin{array}{l}\text { Çevrimiçi Satın } \\
\text { Alma Niyeti }\end{array}$} & 1 Saate Kadar & \multicolumn{2}{|c|}{-} & \multicolumn{2}{|c|}{-} & \multicolumn{2}{|c|}{ * } \\
\hline & 1 ile 2 Saat Arası & \multicolumn{2}{|c|}{-} & \multicolumn{2}{|c|}{-} & \multicolumn{2}{|c|}{ - } \\
\hline & 3 Saat ve Üzeri & \multicolumn{2}{|c|}{ * } & \multicolumn{2}{|c|}{-} & \multicolumn{2}{|c|}{ - } \\
\hline
\end{tabular}

Katılımcıların sosyal medya ziyaret sıklıklarının bağımlı değişken açısından anlamlı bir fark oluşturup oluşturmadığını gözlemlemek için yapılan fark testlerinde "çevrimiçi satın alma niyeti” kapsamında anlamlı farklılıklar gözlemlenmiştir. Anlamlı 
farklılıkların gözlemlendiği "çevrimiçi satın alma niyeti”nde Tablo 5 'te görüldüğü üzere sosyal medyaya $6 \mathrm{kez}$ ve üstü girenlerin ortalamalarının, 1-5 kez girenlerden yüksek olduğu tespit edilmiştir. Dolayısı ile bu, sosyal medyaya girme sıklığının "çevrimiçi satın alma niyeti" üzerinde artı yönde bir değişim meydana getirdiğini göstermektedir. Bu doğrultuda çalışmanın üçüncü hipotezi kabul edilmiştir.

Tablo 5: Günlük Sosyal Medya Ziyaret Sıklığı Fark Testleri

\begin{tabular}{|c|c|c|c|c|c|c|c|}
\hline \multicolumn{8}{|c|}{ Bağımsız Değişken: Günlük Sosyal Medya Ziyaret Sıklığı } \\
\hline Bağımlı Değişken & Bağımsız Değişken & $\mathbf{N}$ & Ortalama & $\begin{array}{c}\text { Standart } \\
\text { Sapma }\end{array}$ & S.D. & $\mathbf{t}$ & $\mathbf{p}$ \\
\hline \multirow{2}{*}{$\begin{array}{l}\text { Çevrimiçi Satın } \\
\text { Alma Niyeti }\end{array}$} & $1-5$ defa & 378 & 2.96 & 1.09 & \multirow{2}{*}{509} & \multirow{2}{*}{-1.82} & \multirow{2}{*}{$\mathrm{p}<0.05$} \\
\hline & 6 ve üstü & 133 & 3.17 & 1.11 & & & \\
\hline
\end{tabular}

Sosyal medyada marka hayranlığının "çevrimiçi satın alma niyeti" üzerinde bir fark yaratıp yaratmadığı ile ilgili olarak yapılan testlerde Tablo 6'daki gibi sonuçlar elde edilmiştir. T-testinden yararlanılan bu analizde sosyal medyadaki marka hayranlığı "çevrimiçi satın alma niyeti" üzerinde istatistiksel olarak anlamlı farklar yaratmıștır. 0.01'lik anlamlılık düzeyinde oluşan farklar incelendiğinde marka hayranlığına evet diyenlerin "ortalamaları" hayır diyenlerinkinden daha yüksek çıkmıştır. Bu marka hayranlığına evet diyenlerin hayır diyenlere oranla "çevrimiçi satın alma niyetine" daha yüksek bir katılım gösterdiğinin göstergesidir. Dolayısı ile dördüncü hipotez kabul edilmiștir.

Tablo 6'daki diğer bir değişken olan sosyal medya üzerinden yeni ürün takibi ile ilgili yapılan t-testinde, takibin de "çevrimiçi satın alma niyeti" üzerinde anlamlı farklılaşmalara neden olduğu tespit edilmiştir. 0.01'lik anlamlılık düzeyinde oluşan farklar incelendiğinde sosyal medya üzerinden yeni ürün takibine evet diyenlerin "ortalamaları" hayır diyenlerinkinden daha yüksek skor elde etmiştir. Bu sebeple çalışmanın beşinci hipotezi kabul edilmiştir.

Tablo 6: Sosyal Medyada Marka Hayranlığı ve Yeni Ürün Takibi Fark Testleri

\begin{tabular}{|c|c|c|c|c|c|c|c|}
\hline \multicolumn{8}{|c|}{ Bağımsız Değişken: Sosyal Medyada Marka Hayranlığı } \\
\hline Bağımlı Değişken & Bağımsız Değişken & $\mathbf{N}$ & Ortalama & $\begin{array}{l}\text { Standart } \\
\text { Sapma }\end{array}$ & S.D. & $\mathbf{t}$ & p \\
\hline \multirow{2}{*}{$\begin{array}{l}\text { Çevrimiçi Satın } \\
\text { Alma Niyeti }\end{array}$} & Evet & 261 & 3.23 & 1.01 & \multirow{2}{*}{564} & \multirow{2}{*}{4.568} & \multirow{2}{*}{$\mathrm{p}<0.01$} \\
\hline & Hayır & 305 & 2.81 & 1.14 & & & \\
\hline \multicolumn{8}{|c|}{$\begin{array}{l}\text { * Bağımlı değişkenin Skewness - Kurtosis istatistiği puanı }-1.5<x<+1.5 \text { aralığında olduğu } \\
\text { gözlemlendiğinden ve bağımsız değişken içerisinde iki grup olduğundan "t-testi” uygulanmıştır. }\end{array}$} \\
\hline \multicolumn{8}{|c|}{ Bağımsız Değişken: Sosyal Medya Üzerinden Yeni Ürün Takibi } \\
\hline Bağımlı Değişken & Bağımsız Değişken & $\mathbf{N}$ & Ortalama & $\begin{array}{l}\text { Standart } \\
\text { Sapma }\end{array}$ & S.D. & $\mathbf{t}$ & p \\
\hline \multirow{2}{*}{$\begin{array}{l}\text { Çevrimiçi Satın } \\
\text { Alma Niyeti }\end{array}$} & Evet & 48 & 3.36 & 1.09 & \multirow{2}{*}{582} & \multirow{2}{*}{2.318} & \multirow{2}{*}{$\mathrm{p}<0.05$} \\
\hline & Hayır & 536 & 2.98 & 1.10 & & & \\
\hline
\end{tabular}

Son bir yıl içinde internetten alınan ürün sayısının "çevrimiçi satın alma niyeti" üzerindeki etkisine bakıldığında, alınan ürün sayısının "çevrimiçi satın alma niyeti" üzerinde anlamlı farklılıkların oluşmasına neden olduğu tespit edilmiştir. Araştırma kapsamında internetten alışveriş yapma sıklığı üç gruba ayrılmıştır. Hangi gruplarda 
anlamlı farklılıklar oluştuğu incelendiğinde, bütün gruplar arasında anlamlı farkların oluştuğu gözlemlenmiştir. Grupların ortalamaları değerlendirildiğinde, internetten daha yüksek alışveriş yapma sıklığına sahip olan grupların daha yüksek ortalamalar elde ettiği görülmüştür. Bu internetten daha sık alışveriş yapmanın "çevrimiçi satın alma niyeti" üzerinde olumlu bir etki yarattığının kanıtı niteliğindedir. Bu doğrultuda çalışmanın altıncı hipotezi kabul edilmiştir.

Tablo 7: Son Bir Yıl İçinde İnternetten Alınan Ürün Sayısı Fark Testleri

\begin{tabular}{|c|c|c|c|c|c|c|}
\hline \multicolumn{7}{|c|}{ Bağımsız Değişken: Son Bir Yıl İçerisinde İnternetten Alınan Ürün Sayısı } \\
\hline Bağımlı Değişken & Bağımsız Değişken & $\mathbf{N}$ & Ortalama & $\begin{array}{c}\text { Standart } \\
\text { Sapma }\end{array}$ & $\mathbf{F}$ & $\mathbf{p}$ \\
\hline \multirow{3}{*}{$\begin{array}{l}\text { Çevrimiçi Satın } \\
\text { Alma Niyeti }\end{array}$} & Hiç & 56 & 2.30 & 1.02 & \multirow{3}{*}{51.004} & \multirow{3}{*}{$\mathrm{p}<0.01$} \\
\hline & 1 - 5 Ürün & 208 & 3.26 & 0.95 & & \\
\hline & 6 ve Üzeri & 132 & 3.78 & 0.81 & & \\
\hline \multicolumn{7}{|c|}{$\begin{array}{l}\text { * Bağımlı değişkenin Skewness - Kurtosis istatistiği puanı }-1.5<x<+1.5 \\
\text { aralığında olduğu gözlemlendiğinden ve bağımsız değişken içerisinde ikiden } \\
\text { fazla grup olduğundan "One Way Anova" testi uygulanmıştır. }\end{array}$} \\
\hline Bağımlı Değişken & Bağımsız Değişken & & Hiç & & & 6 ve Üzeri \\
\hline \multirow{3}{*}{$\begin{array}{l}\text { Çevrimiçi Satın } \\
\text { Alma Niyeti }\end{array}$} & Hiç & & - & \multicolumn{2}{|c|}{ * } & * \\
\hline & 1 - 5 Ürün & & * & \multicolumn{2}{|c|}{ - } & * \\
\hline & 6 ve Üzeri & & * & \multicolumn{2}{|c|}{ * } & - \\
\hline
\end{tabular}

Çalışmanın bir diğer fark testi olan son bir yıl içinde internetten alınan ürünlere harcanan paranın araştırma "çevrimiçi satın alma niyeti” üzerinde nasıl bir değişim yarattığına dair yapılan fark testi sonuçları Tablo 8' deki gibidir. Tablo 8 incelendiğinde "çevrimiçi satın alma niyeti" üzerinde son bir yılda harcanan paranın anlamlı farklara neden olduğu görülmektedir. Araștırmada katılımcıların internet üzerinden son bir yıl içinde aldıkları ürünlere harcadıkları para miktarı 3 gruba ayrılmıştır. "Çevrimiçi satın alma niyeti” üzerinde bütün harcama grupları arasında anlamlı farklar gözlemlenmiștir. Ayrıca harcama gruplarının ortalamalarına bakıldığında daha yüksek harcama gruplarının daha yüksek ortalamalar aldığı gözlemlenmiştir. Bu artan harcama düzeyinin "çevrimiçi satın alma niyeti” üzerindeki etkisinin nasıl olduğuna dair ipucu niteliğinde bir veridir. Dolayısı ile çalışmanın yedinci hipotezi de kabul edilmiştir.

Tablo 8: Son Bir Yll İçinde İnternetten Alınan Ürünlere Harcanan Para Fark Testleri

\begin{tabular}{|c|c|c|c|c|c|c|}
\hline \multicolumn{7}{|c|}{ Bağımsız Değişken: Son Bir Yıl İçerisinde İnternetten Alınan Ürünlere Harcanan Para } \\
\hline Bağımlı Değişken & Bağımsız Değişken & $\mathbf{N}$ & Ortalama & $\begin{array}{c}\text { Standart } \\
\text { Sapma }\end{array}$ & $\mathbf{F}$ & p \\
\hline \multirow{3}{*}{$\begin{array}{l}\text { Çevrimiçi Satın } \\
\text { Alma Niyeti }\end{array}$} & Hiç & 132 & 2.22 & 1.03 & \multirow{3}{*}{88.461} & \multirow{3}{*}{$\mathrm{p}<0.01$} \\
\hline & $1-250 \mathrm{TL}$ & 210 & 3.18 & 0.88 & & \\
\hline & 250 ve Üstü & 151 & 3.77 & 0.91 & & \\
\hline \multicolumn{7}{|c|}{$\begin{array}{l}\text { * Bağımlı değişkenin Skewness - Kurtosis istatistiği puanı }-1.5<x<+1.5 \\
\text { aralığında olduğu gözlemlendiğinden ve bağımsız değişken içerisinde ikiden } \\
\text { fazla grup olduğundan "One Way Anova" testi uygulanmıştır. }\end{array}$} \\
\hline Bağımlı Değişken & Bağımsız Değişken & & liç & 1-250 TL & 250 & e Üstü \\
\hline \multirow{3}{*}{$\begin{array}{l}\text { Çevrimiçi Satın } \\
\text { Alma Niyeti }\end{array}$} & Hiç & \multicolumn{2}{|c|}{-} & * & \multicolumn{2}{|c|}{ * } \\
\hline & $1-250 \mathrm{TL}$ & \multicolumn{2}{|c|}{ * } & - & \multicolumn{2}{|c|}{ * } \\
\hline & 250 ve Üstü & \multicolumn{2}{|c|}{ * } & * & \multicolumn{2}{|c|}{-} \\
\hline
\end{tabular}

Araştırmanın son fark testleri, katılımcıların sosyal medyayı kullanma nedenlerinin "çevrimiçi satın alma niyeti" üzerindeki etkisini gözlemlemek için yapılmıştır. 
Tablo 9'da görüldügü üzere katılımcıların "çevrimiçi alışveriş niyetleri” üzerinde sosyal medyanın "fotoğraf yüklemek/bakmak", "zaman geçirmek", "insanlara kolay erișim", "profil okuma" ve "yeni arkadaș edinme" amaçlı kullanımları anlamlı farklar yaratmıştır. "Sosyal gruplardan haberdar olma" ve "arkadaşlık ilişkilerini sürdürme" amaçlı kullanım davranışlarının ise "çevrimiçi satın alma niyeti" üzerinde istatistiksel olarak anlamlı farklar yaratmadı̆̆ı gözlemlenmiştir.

Tablo 9: Sosyal Medyayı Kullanma Nedenlerine İlişkin Fark Testleri

\begin{tabular}{|c|c|c|c|c|c|c|c|}
\hline Bağımsız Değişken & $\begin{array}{l}\text { Kullanım } \\
\text { Durumu }\end{array}$ & $\mathbf{N}$ & Ortalama & $\begin{array}{c}\text { Standart } \\
\text { Sapma }\end{array}$ & S.D. & $\mathbf{t}$ & $\mathbf{p}$ \\
\hline \multirow[b]{2}{*}{ Fotoğraf Yüklemek/Bakmak } & Hayır & 295 & 2,86 & 1.13 & \multirow{2}{*}{581} & \multirow{2}{*}{-3.171} & \multirow{2}{*}{$p<0.01$} \\
\hline & Evet & 288 & 3.15 & 1.05 & & & \\
\hline \multirow{2}{*}{$\begin{array}{l}\text { Sosyal Gruplardan } \\
\text { Haberdar Olmak }\end{array}$} & Hayır & 206 & 2.97 & 1.12 & \multirow{2}{*}{581} & \multirow{2}{*}{-0.627} & \multirow{2}{*}{ p? 0.05} \\
\hline & Evet & 377 & 3.03 & 1.09 & & & \\
\hline \multirow{2}{*}{$\begin{array}{l}\text { Arkadaşlık İlişkilerini } \\
\text { Sürdürmek }\end{array}$} & Hayır & 343 & 2.98 & 1.09 & \multirow{2}{*}{582} & \multirow{2}{*}{-0.703} & \multirow{2}{*}{ p? 0.05} \\
\hline & Evet & 241 & 3.05 & 1.10 & & & \\
\hline \multirow{2}{*}{ Zaman Geçirme } & Hayır & 193 & 2.77 & 1.17 & \multirow{2}{*}{582} & \multirow{2}{*}{-3.763} & \multirow{2}{*}{$\mathrm{p}<0.01$} \\
\hline & Evet & 391 & 3.13 & 1.04 & & & \\
\hline \multirow{2}{*}{ İnsanlara Kolay Erişim } & Hayır & 226 & 2.89 & 1.08 & \multirow{2}{*}{582} & \multirow{2}{*}{-1.999} & \multirow{2}{*}{$\mathrm{p}<0.05$} \\
\hline & Evet & 358 & 3.08 & 1.10 & & & \\
\hline \multirow{2}{*}{ Profil Okuma } & Hayır & 445 & 2.93 & 1.11 & \multirow{2}{*}{582} & \multirow{2}{*}{-3.018} & \multirow{2}{*}{$\mathrm{p}<0.01$} \\
\hline & Evet & 139 & 3.25 & 1.01 & & & \\
\hline \multirow{2}{*}{ Yeni Arkadaş Edinme } & Hayır & 505 & 2.97 & 1.10 & \multirow{2}{*}{582} & \multirow{2}{*}{-2.067} & \multirow{2}{*}{$\mathrm{p}<0.05$} \\
\hline & Evet & 79 & 3.25 & 1.08 & & & \\
\hline \multicolumn{8}{|c|}{$\begin{array}{l}\text { * Bağımlı Değişken: Çevrimiçi Satın Alma Niyeti } \\
\text { ** Bağımlı değişkenin Skewness - Kurtosis istatistiği puanı }-1.5<x<+1.5 \text { aralığında olduğu } \\
\text { gözlemlendiğinden ve bağımsız değişkenlerin içerisinde iki grup olduğundan "t-testi" uygulanmıştır. }\end{array}$} \\
\hline
\end{tabular}

\section{Sonuç}

İnternet kullanımının toplumun hemen hemen her kesiminde yaygınlaşması, günümüzde bireyin yaşamına dair birçok alanda köklü değişime neden olduğu gibi tüketicilerin tutum ve davranışlarında da önemli değişimlere neden olmuştur. Özellikle ürün ve hizmetleri satın alma davranışlarında meydana gelen değişim bu alanda en çok üzerinde durulan konulardandır (Forsythe ve Shi, 2003, 868). Gerek ürün ve hizmetler hakkında fikir edinmede, gerek ürün ve hizmetlere ulaşmada, gerekse de bu ürün ve hizmetleri satın almada eskisinden farklı imkânlara kavuşan tüketicinin satın alma davranış niyeti hem uygulayıcılar hem de akademisyenler için üzerinde durulan önemli araştırma konularından birisi olmuştur.

Tüketicilerin internet üzerinden satın alma karar süreçlerinde birçok unsur etki edebilmektedir. Bu unsurlar kişilikleri, ait oldukları kültür, o güne kadar edindikleri bilgiler, sosyal sınıfları, aileleri, internet ve sosyal medya deneyimleri, çeşitli demografik özellikler vb. şeklinde sıralanabilir. Alanyazındaki kimi çalışmalarda tüketicilerin internet üzerinden alışveriş yapma davranışlarını anlamaya çalışılırken, kimi çalışmada ise kişisel tutum ve tavırların internet üzerinden alışveriş yapma davranışlarına olan etkileri tartışılmıştır. $\mathrm{Bu}$ çalışmada tüketicilerin çevrimiçi alışveriş niyetleri üzerinde etkili olduğu düşünülen internet ve sosyal medya kullanımlarına ilişkin bazı değişkenlerin etkileri gözlemlenmeye çalışılmıştır.

Araştırma kapsamında "çevrimiçi satın alma niyeti” üzerinde etkisi gözlemlenmeye çalışılan ilk değişken, bireylerin internette geçirdikleri ortalama süre olmuştur. 
Çalışma kapsamda yapılan fark testlerinde internette geçirilen ortalama sürenin "çevrimiçi satın alma niyeti" üzerinde fark yarattığı gözlemlenmiştir. Özellikle hangi gruplar arasında fark gözlemlendiği ve fark kaynaklı etkinin nasıl bir yönde olduğu incelendiğinde de farklar bütün gruplar arasında anlamlı bir şekilde oluşmuştur. Özellikle grup ortalamaları incelendiğinde internette geçirilen süre arttıkça "çevrimiçi satın alma niyeti" ne ilişkin ortalamalar da yükselmektedir. Ulaşılan bu sonuç internette geçirilen sürenin bireylerin "çevrimiçi satın alma niyeti"ni arttırdığına yönelik bir işarettir. Dolayısı ile internette geçirilen süre arttıkça bireylerin internet üzerinden alışveriş yapma eğilimlerinin de artacağı mevcut araştırma sınırlılıkları ile söylenebilmektedir.

Çalışmada "çevrimiçi satın alma niyeti" üzerinde etkisi gözlemlenmeye çalışılan ikinci değişken ise kullanıcıların gün içinde sosyal medyada geçirdikleri ortalama süredir. Değişken ile ilgili yapılan fark testlerinde gün içinde sosyal medyada geçirilen sürenin "çevrimiçi satın alma niyeti" üzerinde pozitif yönlü etkisi gözlemlenmiştir. $\mathrm{Bu}$ veriler eşliğinde sosyal medyada geçirilen süre arttıkça, bireylerin elektronik alışverişe karşı olan niyetleri de artmaktadır denebilir. "Çevrimiçi satın alma niyeti" üzerinde etkisi gözlemlenen bir diğer değişken de, gün içinde sosyal medyaya girme sıklığıdır. Bu etkiyi gözlemlemek için yapılan fark testlerinde sosyal medyaya girme sıklığının "çevrimiçi satın alma niyeti" üzerinde etkisi görülmüştür. Sosyal medyanın günümüzde geldiği nokta itibari ile tüketicinin markalara ilişkin görüş ve düşüncelerinin oluşmasında önemli bir ortam haline geldiği birçok akademik çalışmada tartışılmaktadır. Özellikle kendi içeriğini sosyal medyada yayabilen birey, birçok konuda olduğu gibi ürün ve hizmetlere ilişkin kendi deneyim ve düşüncelerini de bu ortamdan aktarabilmektedir. Birçok bireyin ürün ve hizmetlere ilişkin deneyimlerini sosyal medyadan paylaşması, sosyal medyanın kullanıcıları açısından ürün ve hizmetlere ilişkin özellikle satın alma davranışı öncesinde bir bilgi havuzuna dönüşmesini sağlamıştır. Ayrıca kurumlar da sosyal medya üzerinden ürün ve hizmetlerinin reklamlarını etkin ve hızlı șekilde yapabilmektedir. Sosyal medyada daha fazla zaman geçiren bireyin, hem sosyal medyada kullanıcılar tarafından oluşturulan ürün ve hizmetlere ilişkin bilgileri hem de kurumlar tarafından iletilen reklamları görme sıklığı artacaktır. Dolayısı ile bunun elektronik ortamlardan yapılabilecek alışveriş davranışına olumlu katkısı olacaktır. Bu noktada yürütülen araştırmanın bulguları alanyazındaki diğer araştırmaların bulguları ile benzeşmiştir (Dehghani ve Tumer, 2015, 598; Çelebi, 2015, 312; Ertugan, 2017, 132; Balakrishnan, Dahnil ve Yi, 2014, 183; Erkan ve Evans, 2016, 47; Shu ve Scott, 2014, 49; Hudson ve Thal, 2013, 156; Hussain, Ahmed, Jafar, Rabnawaz and Jianzhou, 2017, 96; Park ve Kim, 2016, 1712; Wang, Yu ve Wei, 2012, 198; Gunawan ve Huarng, 2015, 1).

Mevcut araştırmada etkisi gözlemlenen bir diğer değişken, sosyal medyadaki marka hayranlığıdır. Çalışma kapsamında sosyal medyadaki marka hayranlığının "çevrimiçi satın alma niyeti" üzerinde nasıl bir etkisi olduğunu gözlemlemek için yapılan fark testlerinde marka hayranı olan bireylerin hayranı olmayan bireylerden daha ortalama değerine sahip olduğu tespit edilmiştir. Bu marka hayranlığının çevrimiçi satın alma niyeti üzerindeki olumlu etkisinin göstergesi niteliğindedir. Sosyal medyada markaya hayran olan bireyler yüksek ilginlik ve marka ile ilgili bilgilerdeki seçici algılarından dolayı elektronik alışverişe daha yatkın olabilmektedirler.

Araştırmada yapılan bir diğer testte bireylerin sosyal medya üzerinden yeni ürün takiplerinin "çevrimiçi satın alma niyeti" üzerindeki etkisi gözlemlenmiştir. Yapılan 
fark testi ile istatistiksel olarak anlamlı şekilde sosyal medyadaki yeni ürün takibinin alışveriș niyetini desteklediği gözlemlenmiştir. Özellikle sosyal medyanın etkileşimli yapısı ve hızlı iletişim olanağı, birçok kişi için bu ortamı ilginliklerinin yüksek olduğu ürünler ile ilgili bir haber medyasına çevirmiştir. Dolayısı ile yeni ürün ve hizmetlerin takibi anlamında sosyal medya önemli bir ortam haline gelmiştir. Çalışmanın bu bulgusu ile sosyal medyanın ilgili işlevinin çevrimiçi alışveriş niyetine olan olumlu etkisi desteklenmiştir.

Bireylerin "çevrimiçi satın alma niyeti"ne etki eden unsurlardan birisi de bu alışveriş çeşidi ile ilgili geçmişteki deneyimleridir. Geçmişte e-alışveriş deneyimi olan bireyin elektronik alışverișe daha yatkın birey olacağı beklenebilmektedir. $\mathrm{Bu}$ kapsamda, araştırmaya katılan bireylerin son bir yıl içinde internetten aldığı ürün sayısı ve bu ürünlere harcanana para miktarı incelenmiștir. Her iki değișkenin "çevrimiçi satın alma niyeti" üzerindeki etkisi test edildiğinde istatistiksel olarak anlamlı farklar bulunmuştur. Alınan ürün sayısında ve harcanan para miktarında artış yaşandıkça çevrimiçi satın alma niyetine ilişkin ortalama değerinde de artışlar gözlemlenmiştir. Dolayısı ile bu sonuç, elektronik ortamlardaki alışveriş sıklığının ve harcanan para miktarının artmasının çevrimiçi satın alma niyetini pozitif yönde desteklediğinin bir göstergesi niteliğindedir.

Araştırma kapsamında sosyal medya kullanım nedenleri ile "çevrimiçi satın alma niyeti" arasındaki ilişki gözlemlendiğinde araștırmaya dahil edilen sosyal medya kullanım nedenlerinden fotoğraf yükleme, zaman geçirme, insanlara kolay erişim ve profil okumanın çevrimiçi alışveriş niyeti ile ilişkisi gözlemlenmiştir. İlişkisi gözlemlenen her değişkende evet diyenlerin ortalamaları hayır diyenlere oranla daha yüksek çıkmıştır. Dolayısı ile bu kullanım amaçlarının “çevrimiçi satın alma niyeti”ni mevcut araştırma sınırlılıkları dâhilinde desteklediğini söylemek mümkündür.

\section{Kaynakça}

Ajzen, I. (1991). The Theory Of Planned Behavior. Organizational Behavior And Human Decision Processes, 50(2), 179-211.

Anderson, J. C. ve Gerbing, D. W. (1988). Structural Equation Modeling In Practice: A Review and Recommended Two-Step Approach. Psychological Bulletin, $103(3), 411$.

Bagozzi, R. P. (1981). Attitudes, İntentions, And Behavior: A Test Of Some Key Hypotheses. Journal Of Personality And Social Psychology, 41(4), 607.

Bagozzi, R. P., Baumgartner, J., ve Yi, Y. (1989). An Investigation Into The Role Of Intentions as Mediators of The Attitude-Behavior Relationship. Journal of Economic Psychology, 10(1), 35-62.

Balakrishnan, B. K., Dahnil, M. I., ve Yi, W. J. (2014). The Impact of Social Media Marketing Medium Toward Purchase Intention and Brand Loyalty Among Generation Y. Procedia-Social and Behavioral Sciences, 148, 177-185.

Bauman, Zygmunt (1999). Çalışma, Tüketicilik ve Yeni Yoksullar, (Ü. Öktem, Çev.), Sarmal Yayınevi, İstanbul.

Byrne, B. M. (2013). Structural Equation Modeling With LISREL, PRELIS, and SIMPLIS: Basic Concepts, Applications, And Programming. Psychology Press. 
Celebi, S. I. (2015). How Do Motives Affect Attitudes and Behaviors Toward Internet Advertising and Facebook Advertising?. Computers in Human Behavior, 51, 312-324.

Chen, S. J., ve Chang, T. Z. (2003). A descriptive model of online shopping process: some empirical results. International Journal of Service Industry Management, 14(5), 556-569.

Chen, L.-D., Gillenson, M. L. ve Sherrell, D. L. (2002). Enticing Online Consumers: An Extended Technology Acceptance Perspective, Information \& Management, 39(8), 705-719.

Chu, S. C., ve Kim, Y. (2011). Determinants of Consumer Engagement In Electronic Word-of-Mouth (E-wom) in Social Networking Sites. International Journal of Advertising, 30(1), 47-75.

Cooper, P. (1989). Comparison Between The UK And US: The Qualitative Dimension, Journal of the Marketing Research Society, 31(4), 509-520.

Coughlan S. (2016) Time Spent Online 'Overtakes Tv' Among Youngsters. Erişim:16.05.2018. BBC http://www.bbc.com/news/education-353996586

Crespo, Á. H. ve del Bosque, I. R. (2008). The Effect Of Innovativeness On The Adoption Of B2C E-Commerce: A Model Based On The Theory Of Planned Behaviour. Computers in Human Behavior, 24(6), 2830-2847.

Çelik, A. H. (2009). Yapısal Eşitlik Modellemesi Ve Bir Uygulama: Genişletilmiş Online Alışveriş Kabul Modeli. Yayınlanmamış Doktora Tezi.

Dehghani, M., ve Tumer, M. (2015). A Research on Effectiveness of Facebook Advertising on Enhancing Purchase Intention of Consumers. Computers in Human Behavior, 49, 597-600.

Erkan, I., ve Evans, C. (2016). The Influence of E-wom in Social Media on Consumers' Purchase Intentions: An Extended Approach to Information Adoption. Computers in Human Behavior, 61, 47-55.

Ertugan, A. (2017). Using Statistical Reasoning Techniques to Describe The Relationship Between Facebook Advertising Effectiveness and Benefits Gained. Procedia Computer Science, 120, 132-139.

Facebook (2018) Temel Hedefleme, Erișim:16.05.2018. https://www.facebook. com/business/help/633474486707199

Facebook Newsroom Statitistics (2018) Erişim:15.05.2018. https://newsroom. fb.com/company-info/

Forsythe, S. M. ve Shi, B. (2003). Consumer Patronage And Risk Perceptions In Internet Shopping. Journal Of Business Research, 56(11), 867-875.

Gillenson, M. L. ve Sherrell, D. L. (2002). Enticing Online Consumers: An Extended Technology Acceptance Perspective. Information and Management, 39(8), 705-719.

Gunawan, D. D., ve Huarng, K. H. (2015). Viral Effects of Social Network And Media on Consumers' Purchase Intention. Journal of Business Research, 68(11), 22372241. 
Hadija, Z., Barnes, S. B., ve Hair, N. (2012). Why We Ignore Social Networking Advertising. Qualitative Market Research: An International Journal, 15(1), 19-32.

Hudson, S., ve Thal, K. (2013). The Impact of Social Media on The Consumer Decision Process: Implications for Tourism Marketing. Journal of Travel ve Tourism Marketing, 30(1-2), 156-160.

Hussain, S., Ahmed, W., Jafar, R. M. S., Rabnawaz, A., ve Jianzhou, Y. (2017). eWOM Source Credibility, Perceived Risk and Food Product Customer's Information Adoption. Computers in Human Behavior, 66, 96-102.

Intention (2018). Merriam-Webster içinde. Erişim: 04 Nisan 2018, https://www. merriam-webster.com/dictionary/intention

Jöreskog, K. G. ve Sörbom, D. (1982). Recent Developments In Structural Equation Modeling. Journal of Marketing Research, 404-416.

Kağıtçıbaşı, Ç., ve Üskül, A. (2006). Yeni İnsan ve İnsanlar: Sosyal Psikolojiye Giriş. İstanbul: Evrim Yayınevi.

Kelly, K. (1999). New Rules For The New Economy: 10 Radical Strategies For A Connected World. Newyork: Penguin.

King, R. A., Racherla, P., ve Bush, V. D. (2014). What We Know And Don't Know About Online Word-of-Mouth: A Review and Synthesis of The Literature. Journal of Interactive Marketing, 28(3), 167-183.

Köseoğlu, Ö. (2012). Sosyal A $\breve{g}$ Sitesi Kullanıcılarının Motivasyonları: Facebook Üzerine Bir Araştırma. Selçuk Üniversitesi İletişim Fakültesi Akademik Dergisi, $7(2), 58-81$.

Köseoğlu, Ö. (2013). Bir Pazarlama İletişimi Ortamı Olarak Facebook: Reklam ve Elektronik Ağızdan Ağıza Mesajların Karşılaştırılmasına Yönelik Bir Analiz. Global Media Journal: Turkish Edition, 3(6), 74-101.

Leelayouthayotin, L. (2004). Factors Influencing Online Purchase Intention: The Case Of Health Food Consumers Yn Thailand. Yayınlanmamış Doktora Tezi, University Of Southern Queensland.

Lenhart, A., Purcell, K., Smith, A. ve Zickuhr, K. (2010). Social Media ve Mobile Internet Use among Teens and Young Adults. Millennials. Pew Internet ve American Life Project.

Lomax, R. G. ve Schumacker, R. E. (2004). A Beginner's Guide To Structural Equation Modeling. Psychology Press.

Mangold, W. G., ve Faulds, D. J. (2009). Social Media: The New Hybrid Element of The Promotion Mix. Business Horizons, 52(4), 357-365.

Mikalef, P., Giannakos, M., ve Pateli, A. (2013). Shopping and Word-of-Mouth Intentions on Social Media. Journal of Theoretical and Applied Electronic Commerce Research, 8(1), 17-34.

Moon, J. W. ve Kim, Y. G. (2001). Extending the TAM for a World-Wide-Web context. Information ve Management, 38(4), 217-230.

Morrison, D. G. (1979). Purchase Intentions And Purchase Behavior. The Journal of Marketing, 43(2), 65-74. 
Park, E. J., ve Kim, E. Y. (2016). Factors Driving Consumer Intentions to Purchase and Word-of-Mouth of Fashion Products on Social Media Sites. Global Marketing Conference at Hong Kong. 1712-1713.

Pereira, H. G., de Fátima Salgueiro, M., ve Mateus, I. (2014). Say Yes to Facebook and Get Your Customers Involved! Relationships In a World of Social Networks. Business Horizons, 57(6), 695-702.

San Martín, H., ve Herrero, Á. (2012). Influence of The User's Psychological Factors on The Online Purchase Intention In Rural Tourism: Integrating Innovativeness to the UTAUT Framework. Tourism Management, 33(2), 341-350.

Sashittal, H. C., Sriramachandramurthy, R., ve Hodis, M. (2012). Targeting College Students on Facebook? How to Stop Wasting Your Money. Business Horizons, 55(5), 495-507.

Shu, M., ve Scott, N. (2014). Influence of Social Media On Chinese Students' Choice of An Overseas Study Destination: An Information Adoption Model Perspective. Journal of Travel ve Tourism Marketing, 31(2), 286-302.

Sorce, P., Perotti, V. ve Widrick, S. (2005). Attitude And Age Differences In Online Buying. International Journal of Retail ve Distribution Management, 33(2), 122-132.

Speck, P. S., ve Elliott, M. T. (1997). Predictors of Advertising Avoidance in Print And Broadcast Media. Journal of Advertising, 26(3), 61-76.

Suh, B. ve Han, I. (2002). Effect of Trust on Customer Acceptance of Internet Banking. Electronic Commerce Research And Applications, 1(3-4), 247-263.

Sweeney, J. C., Soutar, G. N., ve Mazzarol, T. (2008). Factors Influencing Word of Mouth Effectiveness: Receiver Perspectives. European Journal of Marketing, 42(3/4), 344-364.

Şimşek, Ö. F. (2007). Yapısal Eşitlik Modellemesine Giriş: Temel İlkeler ve LISREL Uygulamaları. Ankara: Ekinoks.

Vrechopoulos, A.P., Siomkos, G.F. ve Doukindis, G.I. (2001). Internet Shopping Adoption by Greek Consumers. European Journal of Innovation Management, $4(3), 142-152$.

Wang, F. ve Head, M. (2007). How Can The Web Help Build Customer Relationships?: An Empirical Study on E-Tailing. Information ve Management, 44(2), 115-129.

Wang, X., Yu, C., ve Wei, Y. (2012). Social Media Peer Communication and Impacts on Purchase Intentions: A Consumer Socialization Framework. Journal of Interactive Marketing, 26(4), 198-208.

Windels, K., Heo, J., Jeong, Y., Porter, L., Jung, A. R., ve Wang, R. (2018). My Friend Likes This Brand: Do Ads with Social Context Attract More Attention on Social Networking Sites?. Computers in Human Behavior, 84, 420-429 